\title{
Procurement of medications in the Brazilian public sector: the search for quality in bidding processes
}

\section{Abstract}

Introduction: The procurement of medicines is a critical stage in the Pharmaceutical Service cycle. It is a very challenging activity within the context of public procurement, as it needs to consider the economicity required by a bidding process and the quality requirements proposed by the National Medicines Policy. To achieve this goal, the pharmacist must draw up a term of reference based on health legislation. Objectives: This work aims at subsidizing the essential information that must be included in a term of reference for the procurement of medicines in order to obtain the same with the highest possible quality. Methods: To do so, searches were conducted in the Scientific Eletronic Library Online (Scielo) and Biblioteca Virtual em Saúde (BVS) databases, being complemented by search at the Judgments of the Acórdãos do Tribunal de Contas da União (TCU), Laws in the Portal da legislação and publications of health in SaudeLegis in order to select the essential items to be included in a term of reference. Results: At the end of the analysis, some important topics were listed that should be considered in a term of reference by electronic procurement for a bidding process. Conclusions: With this work we expect to contribute to the elaboration of more robust terms of reference that allow the procurement of medicines with better quality.

Keywords: Competitive Bidding. Drugs. Pharmaceutical Services. Public Sector

\section{Aquisição de medicamento no setor público brasileiro: a busca pela qualidade nos processos licitatórios}

\section{Resumo}

Introdução: A aquisição de medicamentos é uma etapa crítica do ciclo da Assistência Farmacêutica. É uma atividade bastante desafiadora quando inserida do contexto das compras públicas, uma vez que precisa unir a economicidade proposta por um processo licitatório aos quesitos de qualidade propostos pela Política Nacional de Medicamentos. Para atingir esse objetivo, deve ser elaborado um termo de referência embasado nas legislações sanitárias. Nesse contexto o farmacêutico tem um papel fundamental: apoiar a elaboração e execução do processo licitatório, em especial, na elaboração do termo de referência. Objetivo: Esse trabalho tem o objetivo de subsidiar as informações essenciais que devem constar em um termo de referência para aquisição de medicamentos visando sua obtenção com a maior qualidade possível. Método: Inicialmente foram realizadas pesquisas nas bases de dados Scientific Eletronic Library Online (Scielo) e Biblioteca Virtual em Saúde (BVS), sendo complementado por busca de Acórdãos do Tribunal de Contas da União (TCU), pelas Leis no Portal da Legislação e publicações de saúde no SaudeLegis com o intuito de selecionar os itens essenciais a constar em um termo de referência. Resultados: Ao término da análise, foram elencados alguns tópicos importantes que devem ser exigidos em um processo licitatório na modalidade de compra por pregão, por meio do termo de referência. Conclusão: Com esse estudo espera-se contribuir para a elaboração de termos de referência mais robustos que permitam a aquisição de medicamentos com melhor qualidade.

Palavras-chave: Assistência Farmacêutica. Setor público. Licitação. Medicamentos
1 Universidade Federal Fluminense

2 Escola Nacional de Saúde Pública/

Fundação Oswaldo Cruz

Submitted: $07 / 06 / 18$

Resubmitted: $16 / 02 / 19$

Accepted: 04/06/19

DOI: $10.30968 /$ rbfhss.2019.102.0413

ISSN online: $2316-7750$

\section{Corresponding Author:}

Aline Amaral Costa

aline_amc@yahoo.com.br 


\section{Introduction}

Since 1998, with the approval of the National Medications Policy (Política Nacional de Medicamentos, PNM), through Ordinance No. 3.916 of the Ministry of Health, Pharmaceutical Assistance (AF) has been considered more broadly. The focus shifted from the availability of drugs to the population and included quality assurance, safe use and production of these drugs to be offered to the population. ${ }^{1,2}$

These attributes of the drugs to be offered, proposed by the PNM, created a challenge for the purchase of medications. This is one of the activities of Pharmaceutical Care Management. Proper drug procurement should consider some stages in the pharmaceutical care cycle: first what to buy (selection); when and how much to buy (schedule); and how to buy (purchase). Proper monitoring and a correct evaluation of processes are paramount to increasing the quality of management. ${ }^{3}$

The challenge is even greater in the case of public purchases, since the Federal Constitution of 1988, in item XXI of article 37, determined the mandatory bidding for the purchase of products, which included the purchase of medications. Thus, the purchase of medications is based on the obligation to buy with quality, as the PNM bases. In addition, the bidding process aimed at the principle of economy So, it became necessary to create strategies to deal with the quality-cost binomial. ${ }^{4,5}$

In Brazil, the two main legislations that serve as the basis for the bidding process are Law No. 8,666/93 and Law No. 10,520/02. The first one presents the bidding, pricing and invitation models and the second one the reverse auction model, the latter being the most used modality for the acquisition of medications. ${ }^{6,7}$

The Term of Reference (TR) is the part of a bidding notice in which the Administration spells out the object. It should systematically and thoroughly document in detail the purpose of the engagement it intends to undertake, as well as contain relevant details that guide the decision during the contest, as well as its contractual phase. Its elaboration is a complex task and must be multi-professional. Although the Law only requires instructing the trading modality, it can be done for any modadilty. ${ }^{8}$

Any complexity involving the "medication" product must be explicit in the Terms of Reference. The pharmacist is an important factor in this process for gathering the competence and the technical knowledge about the medications, being able to act in the acquisition part in the elaboration of the TR as well as in the issuance of technical opinions. Knowing the sanitary legislation, the market and the purchasing legislation, especially in cases where the process is being conducted within the public service, is an essential factor for the success of the acquisition. Timely supply of adequate quality medications crowns every effort. ${ }^{9}$

Considering the specificity of the pharmaceutical market, which is very complex, dynamic and competitive, guided by constantly changing legal dictates, the term of reference for the acquisition of this type of supply should be carefully prepared. The aim of this study was to review the literature and the administrative and health standards related to the procurement of medications in the public sector and the quality aspects during the purchase process. Given this, the essential information that should be included in a reference term was added to seek to obtain higher quality drugs at the lowest cost.

\section{Methods}

This research was based on the documentary survey that regulates the procurement of medications for the public service. The search was done through an Internet research on the rules that guide the bidding processes and the sanitary laws that underlie the acquisition of medications.

Publications were collected from the following databases: Scientific Electronic Library Online (Scielo) and Virtual Health Library (Biblioteca Virtual em Saúde, VBS), complemented by a search of Judgments of the Federal Court of Accounts (Tribunal de Contas da União, TCU), by the Laws in the Legislation Portal and by health publications in SaudeLegis.1

The importance of seeking the Judgments is that the TCU is the autonomous and independent body to which the Constitution assigns competence to exercise the external control of the Federal Public Administration in the examination of financial and budgetary acts. They have the important and indispensable task of supervising the revenue and expenditure of the Union's entities. Their decisions are expressed through Judgments. ${ }^{10}$
For the intended survey, different search strategies were employed in view of the specificities of each database. The keywords used were the following: "medication", "bidding", "acquisition", "public procurement", "pharmaceutical assistance" and "financing". Combinations were made using the logical operator "AND". Only decisions in Portuguese, English and Spanish were considered, excluding those that were not directly concerned with the subject or did not deal with the acquisition in Brazil. No search period was established, as it was not an objective to exhaust the publications on the subject. Subsequently, only those that best covered the context of the study were selected, based on their interest in generalized drug acquisition issues.

The descriptors for the search for normative acts and legislations were as follows: "medications"; "purchases and medications"; "care and pharmaceutical"; "public procurement and medications" and "health surveillance". For these, the inclusion criterion was that the rules were in force, and the rules for specific drugs were excluded.

From the survey carried out, the points that are essential to be considered for the purchase of medications were selected, aiming at the quality of the items purchased, based on the sanitary rules for the acquisition of current drugs.

This study is one of the results of the Project Analysis of Terms of Reference of Procurement Tenders for the Procurement of Medications in the Public Sector approved by the Ethics and Research Committee of the Fluminense Federal University (CAAE 71089417.5.0000.5243; Opinion No. 2,298,759) and executed in accordance with the ethical commitment made. The results herein presented involved public consultations only and no human research was involved.

\section{Results}

Through the bibliographic search in the searched databases 92 articles were listed. Of this total, repeated articles were excluded, reducing the total to 85. Analyzing the abstracts of these articles, 10 articles related to the theme were selected.

When searching the Laws in the Legislation Portal (Plateau) and health publications in SaudeLegis, 254 existing laws were identified using the terms "medications"; "purchases and medications"; "care and pharmaceutical"; "public procurement and medications" and "health surveillance". It was observed that, of these, 171 are active. However, only 20 were considered as affecting the proposed theme.

In the search for Judgments on the TCU website, using the terms "acquisition" and "medications", 234 Judgments were found. After analyzing the summary, 85 Judgments were extracted. Only themes not affected to the problem studied or specific drug specificities were excluded.

Considering the entire executed and predicted search, we elaborated Figure 1 and 2 that intend to present an overview of the rules that can support the elaboration of a TR

\section{Discussion}

The search for the articles was important for the authors' reasoning about what characteristics the drugs need to have to be considered of quality, having the obtaining of the drug as the point of analysis.

The most outstanding articles were those by Merisio et al, ${ }^{11}$ who observed the acquisition of medications in diverse municipalities of Santa Catarina; Pereira et al, ${ }^{12}$ who conducted a study of the evaluability of the pharmaceutical services in Primary Health Care focusing on the availability of medications to the population; Brito, ${ }^{13}$ who studied the acquisition of medications in the public service from the perspective of judicialization; Luiza et al. ${ }^{14}$ who analyzed the procurement of medications in the public sector, focusing on the quality-cost binomial; and Osorio-de-Castro et al., ${ }^{15}$ who suggested a drug procurement protocol in public institutions. All selected articles have in common the concern with the quality of the medications offered to the population and how much the pharmaceutical professional can contribute to improve this process. 
Figure 1. Overview of the rules that can support the development of a drug procurement TR with regard to administrative requirements. (Continued)

\begin{tabular}{|c|c|c|c|}
\hline \multicolumn{4}{|c|}{ Administrative Requirements } \\
\hline & \multirow{2}{*}{\begin{tabular}{|l}
\multicolumn{1}{|c}{ Process } \\
Requesting Unit/ \\
Company - Identification \\
in process header and \\
presentation topic
\end{tabular}} & \multirow{2}{*}{ Objective } \\
\hline Law 10,520/02,7 Art. 3, I & $\begin{array}{l}\text { Art. } 3 \text { The preparatory phase of the reverse auction session will observe } \\
\text { the following: } \\
\text { I - The competent authority shall justify the need for contracting and }\end{array}$ & & \\
\hline $\begin{array}{l}\text { Law 10,520/02,7 Art. 3, } \\
\text { I and III }\end{array}$ & $\begin{array}{l}\text { II - The definition of the object must be precise, sufficient and clear, } \\
\text { prohibiting specifications that, by excessive, irrelevant or unnecessary, } \\
\text { limit the competition; }\end{array}$ & Justification of contracting. & $\begin{array}{l}\text { Clarifies why this bidding is being made } \\
\text { and the intention of the purchase. }\end{array}$ \\
\hline Law 10,520/02,7 Art. 3, II & $\begin{array}{l}\text { III - The records of the procedure shall contain the justification of the } \\
\text { definitions referred to in item I of this article and the indispensable } \\
\text { technical elements on which they are supported, as well as the budget, }\end{array}$ & Object identification topic. & $\begin{array}{l}\text { Specifies the type of material being } \\
\text { ordered. }\end{array}$ \\
\hline $\begin{array}{l}\text { Law 10,520/02,7 Art. } 3 \text {, } \\
\text { III }\end{array}$ & $\begin{array}{l}\text { prepared by the bidding body or entity, of the goods or services to be } \\
\text { bid. }\end{array}$ & $\begin{array}{l}\text { Price survey presentation } \\
\text { with estimated value for } \\
\text { contracting. }\end{array}$ & $\begin{array}{l}\text { Stipulates the maximum and minimum } \\
\text { value practiced by the market, ensuring } \\
\text { the feasibility of the price. }\end{array}$ \\
\hline $\begin{array}{l}\text { Tax liability law } \\
\text { - Complementary } \\
\text { Law 101/00,28 Art. } 16 \text { in } \\
\text { particular }\end{array}$ & $\begin{array}{l}\text { LRF - Lc No. } 101 \text { of May 4, } 2000 \\
\text { It sets public finance standards for fiscal management responsibility } \\
\text { and takes other measures. } \\
\text { Art. 16. The creation, expansion or refinement of government action } \\
\text { that entails increased expenditure will be accompanied by: } \\
\text { I - An estimate of the budgetary-financial impact in the year in which it } \\
\text { is expected to come into force and in the two subsequent ones; } \\
\text { II - A statement by the expenditure authorizing officer that the increase } \\
\text { has budgetary and financial adequacy with the annual budget law and } \\
\text { compatibility with the multi-annual plan and the budget guidelines } \\
\text { law. }\end{array}$ & $\begin{array}{l}\text { Budget Appropriation } \\
\text { Spending Object - The } \\
\text { price surveys with the } \\
\text { expected quantity to buy } \\
\text { result in the amount of } \\
\text { what you want to spend } \\
\text { during the validity of the } \\
\text { notice. }\end{array}$ & $\begin{array}{l}\text { Guaranteed spending planning for } \\
\text { possible future payment in case of } \\
\text { execution of object.1 }\end{array}$ \\
\hline $\begin{array}{l}\text { Art. 4, III and XIII } \\
\text { of Law 10,520/027 } \\
\text { and Art. } 45 \text {, item I of } \\
\text { Law 8,666/93.6 }\end{array}$ & $\begin{array}{l}\text { Art. } 4 \text { The external phase of the reverse auction session will start with the } \\
\text { call of interested parties and will observe the following rules: } \\
\text { XIII - Qualification will be made with the verification that the bidder is } \\
\text { in a regular situation before the National Treasury, Social Security and } \\
\text { the Working Time Guarantee Fund (Fundo de Garantia do Tempo } \\
\text { de Serviço, FGTS), and the State and Municipal Treasuries, when } \\
\text { applicable, with the proof that it meets the requirements of the notice } \\
\text { regarding legal qualification and technical and economic qualifications; } \\
\text { Art. } 45 \text {. Judgment of the proposals will be objective, and the } \\
\text { Bidding Commission or the person responsible for the invitation } \\
\text { must carry it out in accordance with the types of bidding, the criteria } \\
\text { previously established in the call notice and in accordance with the } \\
\text { factors exclusively referred to therein, so as to enable them to be } \\
\text { evaluated by the bidders and by the control bodies. } \\
\text { I - The lowest price - When the selection criterion of the most } \\
\text { advantageous proposal for the Administration determines that the } \\
\text { bidder who submits the proposal in accordance with the specifications } \\
\text { of the invitation to bid and offers the lowest price will be the winner; }\end{array}$ & $\begin{array}{l}\text { Qualification Conditions, } \\
\text { among others if necessary }\end{array}$ & $\begin{array}{l}\text { It seeks the quality of the registered } \\
\text { suppliers, all having to present the } \\
\text { necessary qualifications to participate } \\
\text { in bids. }\end{array}$ \\
\hline $\begin{array}{l}\text { Law 10,520/02,7 Art. 3, } \\
\text { I and III; }\end{array}$ & $\begin{array}{l}\text { Art. } 3 \text { The preparatory phase of the reverse auction session will observe } \\
\text { the following: } \\
\text { I - the competent authority will justify the need for contracting and } \\
\text { will define the object of the contest, the qualification requirements, the } \\
\text { criteria for the acceptance of bids, the penalties for non-compliance } \\
\text { and the terms of the contract, including setting deadlines for delivery; } \\
\text { III - The case file will contain the justification for the definitions } \\
\text { referred to in item I of this article and the indispensable technical } \\
\text { elements on which they are based, as well as the budget, prepared by } \\
\text { the bidding agency or entity, of the goods or services to be bid; }\end{array}$ & $\begin{array}{l}\text { Qualification Conditions, } \\
\text { among others if necessary }\end{array}$ & $\begin{array}{l}\text { It seeks the quality of the registered } \\
\text { suppliers, all having to present the } \\
\text { necessary qualifications to participate } \\
\text { in bids. }\end{array}$ \\
\hline
\end{tabular}


Figure 1. Overview of the rules that can support the development of a drug procurement TR with regard to administrative requirements. (Continued)

\begin{tabular}{|c|c|c|c|}
\hline $\begin{array}{l}\text { Art. } 4, X V I \text { and } 73 \text { to } 76 \text { - } \\
\text { Law No. 8,666/936 }\end{array}$ & $\begin{array}{l}\text { Art. } 73 \text {. Once the contract is executed, its object will be received: } \\
\text { II - In the case of equipment purchases or leasing: } \$ 1 \text { In the case of } \\
\text { the purchase of large equipment, the receipt shall be made under a } \\
\text { detailed term and, in the others, by receipt. } \\
\$ 2 \text {. Provisional or definitive receipt does not exclude civil liability for } \\
\text { the solidity and safety of the work or service, or ethical-professional for } \\
\text { the perfect performance of the contract, within the limits established by } \\
\text { the law or the contract. } \\
\$ 4 \text {. In the event that the detailed term or the verification referred } \\
\text { to in this article are not, respectively, drawn up or carried out } \\
\text { within the established deadlines, they will be considered as realized, } \\
\text { provided that they are communicated to the Administration within } \\
15 \text { (fifteen) days prior to their exhaustion. } \\
\text { Art. } 75 \text {. Except as otherwise provided in the notice, invitation or normative } \\
\text { act, the trials, tests and other evidence required by official technical } \\
\text { standards for the proper execution of the object of the contract shall be } \\
\text { borne by the contractor. } \\
\text { Art. } 76 \text {. The Administration will reject all or part of the work, service or } \\
\text { supply performed in breach of contract. }\end{array}$ & $\begin{array}{l}\text { Object Receipt } \\
\text { Conditions }\end{array}$ & $\begin{array}{l}\text { It seeks to regulate the conditions } \\
\text { under which the contracted object } \\
\text { will be received. The legislation } \\
\text { focuses on the provisional and } \\
\text { definitive receipt deadlines. }\end{array}$ \\
\hline Art. 40 of Law 8,666/936 & $\begin{array}{l}\text { Art. 40. In the preamble, the edict shall contain the annual serial number, } \\
\text { the name of the division concerned and its sector, the modality, the regime } \\
\text { of execution and the type of bidding, the mention that it will be governed } \\
\text { by this Law, the place, the day and time for receipt of the documentation } \\
\text { and proposal, as well as for the opening of envelopes, and shall indicate the } \\
\text { following: II - Term and conditions for signing the contract or withdrawing } \\
\text { the instruments, as provided for in Art. } 64 \text { of this Law, for the execution of } \\
\text { the contract and for delivery of the object of the bidding; }\end{array}$ & $\begin{array}{l}\text { Place of Delivery (full } \\
\text { address, telephone, time, } \\
\text { etc.) }\end{array}$ & $\begin{array}{l}\text { It establishes the place where the } \\
\text { contract should be executed and the } \\
\text { conditions for its execution. }\end{array}$ \\
\hline $\begin{array}{l}\text { Art. 3, I of } \\
\text { Law 10,520/02.7 }\end{array}$ & $\begin{array}{l}\text { Art. } 3 \text { The preparatory phase of the reverse auction session will observe } \\
\text { the following: } \\
\text { I - The competent authority shall justify the need for contracting and } \\
\text { will define the object of the contest, the qualification requirements, the } \\
\text { criteria for the acceptance of bids, the penalties for non-compliance } \\
\text { and the terms of the contract, including setting of deadlines for supply; }\end{array}$ & Deadline & $\begin{array}{l}\text { It sets out the period that the } \\
\text { Administration has proposed for the } \\
\text { performance of the contract. }\end{array}$ \\
\hline Art. 67 of Law 8,666/936 & $\begin{array}{l}\text { Art. } 67 \text {. The performance of the contract shall be monitored and } \\
\text { supervised by a specially designated Administration representative, } \\
\text { who may hire third parties to assist him and to provide him with } \\
\text { information relevant to such assignment. }\end{array}$ & Contract Manager & $\begin{array}{l}\text { It intends to clarify the person } \\
\text { responsible for monitoring the } \\
\text { performance of the contract in } \\
\text { accordance with the established rules. }\end{array}$ \\
\hline $\begin{array}{l}\text { Judgement } \\
2368 / 201326 \text { - plenary } \\
\text { session, tc } 035.358 / 2012- \\
2\end{array}$ & $\begin{array}{l}\text { In the reverse auction modality, the requirement to submit samples } \\
\text { before the bidding phase is prohibited, and the obligation should be } \\
\text { imposed only on the provisionally ranked bidder. }\end{array}$ & Samples & $\begin{array}{l}\text { The requirement and sample analysis } \\
\text { are often a highly beneficial procedure } \\
\text { for making good acquisitions, especially } \\
\text { when the valuation criterion is the } \\
\text { lowest price. It is interesting in case } \\
\text { there are questions about the quality } \\
\text { of the packaging, for example, drug } \\
\text { evaluation drug packaged in a syringe. }\end{array}$ \\
\hline $\begin{array}{l}\text { Art. 54, of Law 8,666/936 } \\
\text { (contract clauses) } \\
\text { and Art. } 3 \text { I of } \\
\text { Law } 10,520 / 02.7\end{array}$ & $\begin{array}{l}\text { Art. } 54 \text {. The administrative contracts dealt with in this Law are } \\
\text { governed by its clauses and by the provisions of public law, applying to } \\
\text { them, in addition, the principles of the general contract theory and the } \\
\text { provisions of private law. } \\
\$ 1 \text { The contracts shall clearly and precisely state the conditions for } \\
\text { their execution, expressed in clauses that define the rights, obligations } \\
\text { and responsibilities of the parties, in accordance with the terms of the } \\
\text { bidding and the proposal to which they are bound. } \\
\text { Art. } 3 \text { The preparatory phase of the reverse auction session will observe } \\
\text { the following: } \\
\text { I- The competent authority shall justify the need for contracting and } \\
\text { will define the object of the contest, the qualification requirements, the } \\
\text { criteria for the acceptance of bids, the penalties for non-performance } \\
\text { and the clauses of the contract, including setting deadlines for delivery. }\end{array}$ & $\begin{array}{l}\text { Obligations of the } \\
\text { Contractor and } \\
\text { Contracting parties }\end{array}$ & $\begin{array}{l}\text { It defines the obligations assumed by } \\
\text { the parties involved. }\end{array}$ \\
\hline
\end{tabular}


Figure 1. Overview of the rules that can support the development of a drug procurement TR with regard to administrative requirements. (Concluded)

\begin{tabular}{|c|c|c|c|}
\hline $\begin{array}{l}\text { Judgment 8,518/201729 } \\
\text { and ICMS Confaz } \\
\text { Agreement 87/200230 }\end{array}$ & $\begin{array}{l}\text { CONFAZ ICMS Agreement } 87 / 2002 \text { provides that the operations } \\
\text { carried out with the drugs and medications listed in its single } \\
\text { annex for Federal, State and Municipal Direct and Indirect } \\
\text { Public Administration bodies and their public foundations (first } \\
\text { clause) are exempt from the ICMS. The TCU's consolidated case } \\
\text { law states that a specific clause regarding the application of the } \\
\text { ICMS Confaz Agreement } 87 / 2002 \text { or of other rules that imply tax } \\
\text { exemption should be included in the notice or waiver term, in order } \\
\text { to ensure equality among the participants, the publicity and the } \\
\text { obtaining of the most advantageous proposal for the Administration. }\end{array}$ & Contractor's Obligation & $\begin{array}{l}\text { The absence of an express mention } \\
\text { to the ICMS discount in the notice } \\
\text { may lead to an inequality among the } \\
\text { bidding companies, at the moment } \\
\text { of bid submission, if there is no clause } \\
\text { that normalizes the bid. }\end{array}$ \\
\hline $\begin{array}{l}\text { Art. 3, I and } 7 \text { of } \\
\text { Law 10,520/02.7 }\end{array}$ & $\begin{array}{l}\text { Art. } 3 \text { The preparatory phase of the reverse auction session will } \\
\text { observe the following: } \\
\text { I - The competent authority will justify the need for contracting and } \\
\text { will define the object of the contest, the qualification requirements, } \\
\text { the criteria for acceptance of bids, the penalties for non-compliance } \\
\text { and the clauses of the contract, including setting deadlines for } \\
\text { supply; } \\
\text { Art. } 7 \text { Anyone who, summoned within the validity period of its } \\
\text { proposal, does not conclude the contract, fails to deliver or present } \\
\text { false documentation required for the event, causes the delay of the } \\
\text { execution of its object, does not keep the proposal, fails or acts in a } \\
\text { fraudulent manner in the execution of the contract, misconducts } \\
\text { or commits tax fraud, will be barred from bidding and contracting } \\
\text { with the Union, States, Federal District or Municipalities and will be } \\
\text { disqualified in the Sicaf, or in the supplier registration systems for up } \\
\text { to } 5 \text { (five) years, without prejudice to fines. }\end{array}$ & \multirow[t]{2}{*}{$\begin{array}{l}\text { Administrative Sanctions } \\
\text { - To define in specific } \\
\text { topics the sanctions that } \\
\text { should be applied to the } \\
\text { companies in case of non- } \\
\text { compliance with the edict/ } \\
\text { TR rules. }\end{array}$} & \multirow{2}{*}{$\begin{array}{l}\text { It seeks to penalize the supplier that } \\
\text { does not comply with the agreement. } \\
\text { It seeks to penalize the supplier that } \\
\text { does not comply with the agreement. }\end{array}$} \\
\hline $\begin{array}{l}\text { Art. } 86 \text { and } 87 \text { of } \\
\text { Law } 8,666 / 936\end{array}$ & $\begin{array}{l}\text { Art. } 86 \text {. The undue delay in the execution of the contract will subject } \\
\text { the contractor to the late-payment penalty, as provided in the } \\
\text { invitation or contract. } \$ 1 \text { The fine referred to by this article shall } \\
\text { not prevent the Administration from unilaterally terminating the } \\
\text { contract and applying other penalties provided for in this Law. } \$ 2 \\
\text { The penalty applied after the regular administrative process will } \\
\text { be deducted from the respective contracted party. } \$ 3 \text { If the fine is } \\
\text { worth more than the value of the guarantee, and the loss of it, the } \\
\text { contracted party shall answer for the difference, which It will be } \\
\text { deducted from payments owed by the Administration or, where } \\
\text { applicable, be collected in court. } \\
\text { Art. } 87 \text {. Due to total or partial non-performance of the contract, } \\
\text { the Administration may, guaranteed the previous defense, apply } \\
\text { the following sanctions to the contracted party: I - Warning, II } \\
\text { - Fine, as provided for in the call instrument or in the contract, III - } \\
\text { Temporary suspension of participation in bidding and impediment } \\
\text { to contract with the Administration, for a period not exceeding } \\
2 \text { (two) years, IV - Declaration of unfitness to bid or contract with } \\
\text { the Public Administration while the determinant reasons for the } \\
\text { sanction persist or until rehabilitation before the proper authority } \\
\text { which applied the penalty is promoted, which will be granted } \\
\text { whenever the contracted party reimburses the Administration for } \\
\text { the resulting losses. }\end{array}$ & & \\
\hline
\end{tabular}


Table 2. Overview of the rules that can support the elaboration of a TR for the acquisition of medications with regard to the technical-sanitary requirements. (Continued)

Technical-sanitary requirements

\begin{tabular}{|c|c|c|c|}
\hline \multicolumn{2}{|r|}{ Rationale } & \multirow{2}{*}{\begin{tabular}{l}
\multicolumn{1}{c}{ Process } \\
$\begin{array}{l}\text { License requirement by the } \\
\text { health agency of the drug } \\
\text { supply companies }\end{array}$
\end{tabular}} & \multirow{2}{*}{\begin{tabular}{l}
\multicolumn{1}{c}{ Objective } \\
$\begin{array}{l}\text { To ensure that the supplier } \\
\text { companies are allowed to } \\
\text { operate for this purpose. }\end{array}$
\end{tabular}} \\
\hline $\begin{array}{l}\text { Law No. } 5,991,18 \\
\text { of December } 17 \text { th, } \\
1973 .\end{array}$ & $\begin{array}{l}\text { Art. } 5 \text { - The trade of drugs, medications and pharmaceutical supplies is } \\
\text { exclusive to the companies and establishments defined in this Law. } \\
\text { Art. } 21 \text { - The trade, dispensing, representation or distribution and the im- } \\
\text { portation or exportation of drugs, medications, pharmaceutical supplies and } \\
\text { related products shall only be carried out by companies and establishments } \\
\text { licensed by the competent sanitary agency of the States, of the Federal Dis- } \\
\text { trict and of the Territories, in accordance with the supplementary legislation } \\
\text { to be issued by them, subject to the provisions of this Law. }\end{array}$ & & \\
\hline $\begin{array}{l}\text { Law No. 5,991,18 } \\
\text { of Decem- } \\
\text { ber } 17 \text { th, } 1973 \text { and } \\
\text { Provisional Mea- } \\
\text { sure No. 2,190-34, of } \\
\text { August 23rd, 2001. }\end{array}$ & $\begin{array}{l}\text { Art. } 15 \text { - The pharmacy and the drugstore must be assisted by a responsible } \\
\text { technician, registered in the Regional Pharmacy Council, as provided by } \\
\text { law. } \\
\$ 1 \text { - The presence of the responsible technician shall be mandatory during } \\
\text { the entire opening hours of the establishment. } \\
\text { Art. } 11 \text {. The provisions of Art. } 15 \text { of Law } 5,991 \text {, of December } 17 \mathrm{th}, 1973 \\
\text { apply to the distributors of medications. }\end{array}$ & $\begin{array}{l}\text { Requirement to have a Tech- } \\
\text { nical Responsible Pharmacist } \\
\text { for the establishment that } \\
\text { markets, dispenses, represents, } \\
\text { distributes and/or imports } \\
\text { medications. }\end{array}$ & $\begin{array}{l}\text { Guarantee to have a pharma- } \\
\text { cist responsible for the techni- } \\
\text { cal product purchased. }\end{array}$ \\
\hline $\begin{array}{l}\text { Law 6,360,16 } \\
\text { of Septem- } \\
\text { ber 23rd, } 1976 \text { and } \\
\text { Law } 13,097 / 2015\end{array}$ & $\begin{array}{l}\text { Art. } 2 \text { - Only the companies authorized by the Ministry of Health for this } \\
\text { purpose and whose establishments have been licensed by the sanitary } \\
\text { agency of the Federative Units in which they are located will be allowed } \\
\text { to extract, produce, manufacture, transform, synthesize, purify, fractionate, } \\
\text { pack, repackage, import, export, store or ship the products referred to in } \\
\text { Art. 1. }\end{array}$ & $\begin{array}{l}\text { ANVISA Authorization } \\
\text { Requirement for medication } \\
\text { supplier companies }\end{array}$ & $\begin{array}{l}\text { To ensure that the supplier } \\
\text { companies are allowed to } \\
\text { operate for this purpose. }\end{array}$ \\
\hline $\begin{array}{l}\text { Law 6,360,16 } \\
\text { of Septem- } \\
\text { ber 23rd, } 1976 \text { and } \\
\text { Law } 13,097 / 2015 \text {. }\end{array}$ & $\begin{array}{l}\text { Art. } 12 \text { - None of the products dealt with in this Law, including the import- } \\
\text { ed ones, may be manufactured, exposed for sale or delivered for consump- } \\
\text { tion before being registered with the Ministry of Health. }\end{array}$ & $\begin{array}{l}\text { Requirement of registration of } \\
\text { all medications in the HM. }\end{array}$ & $\begin{array}{l}\text { Guarantee that the medication } \\
\text { is authorized for consumption } \\
\text { in Brazil. }\end{array}$ \\
\hline $\begin{array}{l}\text { Law 9,782,31 of } \\
\text { January 26th, } 1999 .\end{array}$ & $\begin{array}{l}\text { It defines the National Health Surveillance System, creates the Nation- } \\
\text { al Health Surveillance Agency, and makes other arrangements. }\end{array}$ & $\begin{array}{l}\text { It defines ANVISA's respon- } \\
\text { sibilities. }\end{array}$ & $\begin{array}{l}\text { It determines that Anvisa shall } \\
\text { be responsible for regulating } \\
\text { the health sector, responsibility } \\
\text { previously attributed to the } \\
\text { Ministry of Health. }\end{array}$ \\
\hline $\begin{array}{l}\text { Law } 9,787,17 \text { of } \\
\text { February } 10 \text { th, } 1999 .\end{array}$ & $\begin{array}{l}\text { Art. } 3 \text { Purchases of medications, under any purchase modality, and the } \\
\text { medical and dental prescriptions of medications, within the scope of the } \\
\text { Unified Health System (Sistema Único de Saúde, SUS), will mandatorily } \\
\text { adopt the Brazilian Common Denomination (Denominação Comum } \\
\text { Brasileira, DCB) or, in its absence, the Common International Denomina- } \\
\text { tion (Denominação Comum Internacional, DCI). }\end{array}$ & $\begin{array}{l}\text { The drug descriptions should } \\
\text { contain the DCB. }\end{array}$ & $\begin{array}{l}\text { It standardizes the description } \\
\text { of the medications. }\end{array}$ \\
\hline $\begin{array}{l}\text { Law } 9,787,17 \text { of } \\
\text { February 10th, } 1999 .\end{array}$ & $\begin{array}{l}\text { Art. } 3 \$ 2 \text { In the case of purchases of medications referred to in the caput } \\
\text { of this article, the generic drug, if any, will have preference over the others } \\
\text { under equal price conditions. }\end{array}$ & $\begin{array}{l}\text { Explicit explanation of the } \\
\text { preference rule for the generic } \\
\text { drug over the others under } \\
\text { equal conditions. }\end{array}$ & $\begin{array}{l}\text { It standardizes the quality of } \\
\text { the purchased medications. It } \\
\text { encourages the consumption } \\
\text { of the generic drug over similar } \\
\text { ones. }\end{array}$ \\
\hline $\begin{array}{l}\text { Law } 9,787,17 \text { of } \\
\text { February } 10 \text { th, } 1999 .\end{array}$ & $\begin{array}{l}\text { Art. } 3 \$ 3 \text { In the edicts, bidding proposals and drug procurement contracts, } \\
\text { within the scope of the SUS, the technical specifications of the products, the } \\
\text { respective quality control methods and the conformity certification system } \\
\text { will be required, as appropriate. }\end{array}$ & $\begin{array}{l}\text { Requirement of a quality con- } \\
\text { trol report of the medications } \\
\text { supplied. The package leaflet } \\
\text { may be required at the time } \\
\text { of bidding to ensure which } \\
\text { product is being offered. }\end{array}$ & $\begin{array}{l}\text { It ensures that the medication } \\
\text { provided has passed a quality } \\
\text { review and that it has been ap- } \\
\text { proved. The package leaflet is } \\
\text { a documentary mechanism to } \\
\text { verify if what is being proposed } \\
\text { is what is being bid. }\end{array}$ \\
\hline $\begin{array}{l}\text { HM Ordi- } \\
\text { nance } 1,818,32 \\
\text { of Decem- } \\
\text { ber } 2 \text { nd, } 1997 \text {. }\end{array}$ & $\begin{array}{l}\text { Art. } 1 \text { It recommends that the purchase and bidding of pharmaceutical } \\
\text { products carried out at federal, state and municipal levels by governmental } \\
\text { services, agreed and contracted by the SUS, include requisites on quality } \\
\text { requirements to be met by the manufacturers of these products. } \\
\text { Single paragraph: The aforementioned requirements include the technical } \\
\text { specifications of the products and the quality control method protocols to } \\
\text { be met by the manufacturers and suppliers of these products. }\end{array}$ & $\begin{array}{l}\text { Requirement of a quality con- } \\
\text { trol report of the medications } \\
\text { supplied. The package leaflet } \\
\text { may be required at the time } \\
\text { of bidding to ensure which } \\
\text { product is being offered. }\end{array}$ & $\begin{array}{l}\text { It ensures that the medication } \\
\text { provided has passed a quality } \\
\text { review and that it has been ap- } \\
\text { proved. The package leaflet is } \\
\text { a documentary mechanism to } \\
\text { verify if what is being proposed } \\
\text { is what is being bid. }\end{array}$ \\
\hline
\end{tabular}


Table 2. Overview of the rules that can support the elaboration of a TR for the acquisition of medications with regard to the technical-sanitary requirements. (Concluded)

\begin{tabular}{|c|c|c|c|}
\hline $\begin{array}{l}\text { Law 8,666/936 } \\
\text { and HM Ordi- } \\
\text { nance 802/9833 }\end{array}$ & $\begin{array}{l}\text { Law } 8,666 \text { - IV and V of Art. } 43 \text { - The Administration shall verify the } \\
\text { compliance of each proposal with the requirements of the invitation to bid } \\
\text { and may only classify proposals that comply with the evaluation criteria } \\
\text { provided for in the call notice. } \\
\text { In the case of package leaflets, the HM Ordinance No. } 802 / 98 \text { must be } \\
\text { observed (it justifies the items that must appear in the package leaflet). }\end{array}$ & $\begin{array}{l}\text { To require the submission of } \\
\text { the package insert/sample of } \\
\text { the bid }\end{array}$ & $\begin{array}{l}\text { It ensures that the item offered } \\
\text { meets the requirements of the } \\
\text { edict. }\end{array}$ \\
\hline $\begin{array}{l}\text { Ordinance } \\
\text { No. } 2,814 / 9819 \\
\text { and Interminis- } \\
\text { terial Ordinance } \\
\text { No. } 1,409 / 201821\end{array}$ & $\begin{array}{l}\text { Art. } 5^{\circ} \text { In purchases and public bids for medications, carried out by its own } \\
\text { services, and agreed upon } \\
\text { by the SUS, the following requirements must be met: } \\
\text { I - Presentation of the State or Municipal Sanitary License; } \\
\text { II - Proof of Operation Authorization of the company participating in the } \\
\text { bidding process; } \\
\text { III - Product Registration Certificate issued by the } \\
\text { Health Surveillance Secretariat, or a copy of the publication in the D.O.U. }\end{array}$ & $\begin{array}{l}\text { Mandatory requirement } \\
\text { of Health License, Health } \\
\text { Authorization and } \\
\text { Registration }\end{array}$ & $\begin{array}{l}\text { It guarantees that the drug } \\
\text { offered is in a state of use } \\
\text { regarding the legal aspects. }\end{array}$ \\
\hline $\begin{array}{l}\mathrm{MO} / \mathrm{HM} \text { Ordi- } \\
\text { nance No. } 344,34 \text { of } \\
\text { May 12th, } 1998 .\end{array}$ & $\begin{array}{l}\text { Art. } 2^{\circ} \text { To extract, produce, manufacture, benefit from, distribute, transport, } \\
\text { prepare, handle, fractionate, import, export, transform, package, repackage, } \\
\text { for any purpose, the substances listed in this Technical Regulation } \\
\text { (ANNEX I) and its updates, or the medications containing them, } \\
\text { it is mandatory to obtain the Special Authorization granted by the } \\
\text { Health Surveillance Secretariat of the Ministry of Health. }\end{array}$ & $\begin{array}{l}\text { Special Authorization } \\
\text { requirement of the supplier of } \\
\text { medications subject to special } \\
\text { control. }\end{array}$ & $\begin{array}{l}\text { Guarantee of a drug supply } \\
\text { with the legal requirements } \\
\text { met, especially psychoactive } \\
\text { drugs. }\end{array}$ \\
\hline $\begin{array}{l}\text { RDC ANVI- } \\
\text { SA 333,35 of No- } \\
\text { vember 19th, } 2003\end{array}$ & It establishes the technical regulation on medication labeling. & $\begin{array}{l}\text { In the case of a medication, it } \\
\text { should contain AT LEAST } \\
\text { the name in the DCB or } \\
\text { in the DCI; the dose; the } \\
\text { pharmaceutical form; and the } \\
\text { route of administration. }\end{array}$ & $\begin{array}{l}\text { It seeks to certify that the } \\
\text { medication received is the } \\
\text { same as the one offered. }\end{array}$ \\
\hline $\begin{array}{l}\text { RDC ANVI- } \\
\text { SA 199,36 of Octo- } \\
\text { ber 26th, } 2006\end{array}$ & $\begin{array}{l}\text { It institutes the simplified electronic notification of medications available } \\
\text { on ANVISA's website. }\end{array}$ & $\begin{array}{l}\text { It establishes the minimum } \\
\text { criteria for simplified } \\
\text { notification medications. }\end{array}$ & $\begin{array}{l}\text { It seeks to define the criteria to } \\
\text { be analyzed when requesting } \\
\text { simplified notification } \\
\text { medications. }\end{array}$ \\
\hline $\begin{array}{l}\text { RDC ANVI- } \\
\text { SA No. } 71,37 \text { of De- } \\
\text { cember } 22 \text { th, } 2009\end{array}$ & $\begin{array}{l}\text { Art. } 39 \text {. The primary and secondary packaging labels of all the medications } \\
\text { for institutional use, regardless the prescription limitation, must have the } \\
\text { phrase «FORBIDDEN FOR SALE» in uppercase with a minimum size of } \\
30 \% \text { of the height of the largest character in the name or, in its absence, in } \\
\text { the generic name. Single paragraph. On the secondary packaging labels, the } \\
\text { phrase should be placed just above the prescription restriction range, or in } \\
\text { an equivalent positioning if not on its main face. }\end{array}$ & $\begin{array}{l}\text { It establishes that the labels } \\
\text { of medications purchased } \\
\text { to meet the demand of a } \\
\text { particular institution must } \\
\text { bear the stamp of } \\
\text { "SALE PROHIBITED TO } \\
\text { TRADE". }\end{array}$ & $\begin{array}{l}\text { It standardizes the criteria of } \\
\text { the medications to be used by a } \\
\text { particular institution. }\end{array}$ \\
\hline
\end{tabular}

Among the sanitary legislations, we highlight Law No. 6,360/1976,16 which provides for the Health Surveillance to which Medications, Drugs, Pharmaceutical Supplies and Related, Cosmetics, Sanitizing and Other Products are subject, and other Provisions; Law No. 9,787/1999 17 establishing the generic medication, providing for the use of generic names in pharmaceutical products and other measures; and Law 5,991/73, ${ }^{18}$ which provides for the Sanitary Control of Trade in Drugs, Medications, Pharmaceutical Supplies and Related, and other Provisions. All are about the essential requirements for a medication.

The following deserve emphasis: MO/MS Ordinance No. 2,814/98, ${ }^{19}$ which established procedures to be observed by producers, importers, distributors and pharmaceutical companies; HM Ordinance No. 2,894/2018 20 amending the previous one by withdrawing the requirement of the Good Manufacturing Practice Certificate; an Interministerial Ordinance MPOG/MS/MCT/MDIC No. 1,409/2018, ${ }^{21}$ which changed the Interministerial Ordinance No. $128 / 2008^{22}$ that established guidelines for the public procurement of medications and drugs by the Unified Health System. These four ordinances deal more directly with items to consider in a medication purchase.

It is important to highlight that, from the analysis of the laws, it was possible to identify: (a) administrative criteria that must be present in any procurement process for all types of material; and (b) health criteria that are specific to medications.

The criteria listed aim to guide the purchase of medications so that the product purchased by the Administration is as appropriate as possible to the needs of the institutions and the laws governing the regulation of medications in Brazil, always seeking the item with the best possible quality. It is noteworthy that the term of reference makes it mandatory to comply with the requirements listed therein.

The reasoning of the Judgments is important because they set the basis for the items that may be required on a reference term, despite the health legislation. The TCU recently released a booklet entitled "Guidelines for public procurement of medicines ${ }^{\prime 23}$ which addresses specific topics in the area of medication procurement and consolidates the recent case law of the TCU regarding each subject addressed. Among the Judgments, the most noteworthy are Judgment No. 4788/2016, ${ }^{24}$ which addresses the provision in internal regulations of the requirement of the Certificate of Good Manufacturing and Control Practices (Certificado de Boas Práticas de Fabricação e Controle, CBPFC) as a technical qualification requirement in medication bids. In this Judgment, the TCU lists four reasons why it is not in favor of the requirement of this document, namely: the absence of a specific legal provision, contrary to Art. 30, item IV, of Law 8,666/1993; ${ }^{6}$ the need to restrictively interpret the Bidding Statute as to the qualification requirements, in consideration of the increased competitiveness of the bids promoted by the Public Administration; the unworthiness of the CBPFC to guarantee the fulfillment of the obligations assumed by the individual before the Public Power; and the excessive nature of the CBPFC requirement, since the effective registration of medications presupposes the prior adoption by the manufacturer of good manufacturing practices. In contrast to the above, Judgment No. $7,783-33 / 15-2^{25}$ is in favor of the CBPFC requirement as it 
understands that it is a quality requirement supported by specific regulations. This deadlock was resolved with Ordinance MO/MS No. 2,894/2018, ,20 where the Ministry of Health excludes the CBPFC as a requirement for qualification or technical qualification. Another relevant Judgment is $2,368 / 2013,{ }^{26}$ which deals with the compatibility of the requirement to present samples with the bids carried out by means of reverse auction, even in electronic form.

Also worth mentioning is the Addition of the Supreme Court Judgment No. $4,105 / 2010,{ }^{27}$ which granted a precautionary measure in a direct action of unconstitutionality to suspend the effectiveness of $\$ 3$, Art. 5 of Ordinance MO/MS No. 2,814/98, ${ }^{19}$ which required the distributing companies to submit a declaration of their accreditation as a distributor with the company that holds the registration of the products, as well as a liability term issued by the distributor, ensuring their delivery within the time and quantity established in the bidding.

Despite all the rules, the bidding process is very dynamic, and the rules are up to the interpretation of the supervisory body which, in the case of the Union, is the Federal Court of Accounts (Tribunal de Contas da União, TCU). This could be evidenced, for example, with regard to the CBPFC requirement, as previously mentioned.

Despite the diversity of medications in Brazil, the legislation offers options that allow the team responsible for elaborating the term of reference to follow in order to be able to purchase quality medications at market prices. This is done by specifying the desirable characteristics of the purchased product, bringing to the purchasing process the weight of the technical experience of the pharmaceutical professional combined with the knowledge of health legislation.

\section{Conclusion}

The biggest challenge in the phase of medication procurement in the public service in Brazil is to combine the technical legislation, which aims at economy, with the sanitary legislation, which aims at product quality and effectiveness, promoting the adequate supply of medication needs.

The document that gathers the characteristics of the item to be acquired, of multidisciplinary elaboration, is the Term of Reference. However, as the process is the purchase of a medication, the pharmacist is an essential professional to support its elaboration.

The present work made it possible to map a broad administrative-sanitary legal framework capable of sustaining the necessary requirements in the elaboration of a term of reference to guarantee the quality in the acquisition of medications.

In this context, the pharmacist should strive to protect users from the use of medications of dubious quality, while also protecting the institution's economic interests, which will ultimately revert to the more rational use of medications. The institution is responsible for supporting and encouraging its efforts, protecting medication users and the interests of the state.

\section{Funding sources}

The research did not receive financing for its realization.

\section{Conflict of interests}

There are no conflicts of interest related to the execution of the study.

\section{Contributors}

AAC contributed with the design, planning, analysis, data interpretation, writing and critical review of the content. GCC and MAB contributed with the design, interpretation of data and critical review of the content. Everyone is responsible for the accuracy and completeness of any part of the work and approves the final version.

\section{Acknowledgments}

To the Pharmacy School of the Fluminense Federal University for promoting the research in the area of pharmaceutical care management and for enabling the accomplishment of works like this

\section{References}

1. Magarinos-Torres R, Osorio-De-Castro CGS, Pepe VLE. Atividades da farmácia hospitalar brasileira para com pacientes hospitalizados: uma revisão da literatura. Ciência \& Saúde Coletiva, 2007a,12(4): 973-984

2. Brazil. Ministry of Health. Portaria no 3.916, de 10 de novembro de 1998. Aprova a Política Nacional de Medicamentos. Brasília, DF Disponível em: http://bvsms.saude.gov.br/bvs/saudelegis/gm/1998/ prt3916_30_10_1998.html

3. Brazil. Ministry of Health. Secretaria de Ciência, Tecnologia e Insumos Estratégicos. Departamento de Assistência Farmacêutica e Insumos Estratégicos. Aquisição de medicamentos para assistência farmacêutica no SUS: orientações básicas - (Série A. Normas e Manuais Técnicos). Brasília; 2006.56 p.

4. Brazil. Constituição da República Federativa do Brasil de 1988. Brasília: Senado Federal, 1988.

5. Luiza VL, Silva RM, Moraes EL, et al. Compras públicas de medicamentos no Brasil: uma análise a partir do marco regulatório. In E-papers Ed. Desafios de operação e desenvolvimento do Complexo Industrial da Saúde, $1^{\text {a }}$ edição. Rio de Janeiro, 2016: 127-157.

6. Brazil. Lei no 8.666, de 21 de junho de 1993. Regulamenta o art. 37, inciso XXI, da Constituição Federal, institui normas para licitações e contratos da Administração Pública e dá outras providências. Brasília, DF. Disponível em: http://www.planalto.gov.br/ccivil_03/leis/18666cons.htm

7. Brazil. Lei no 10.520 , de 17 de julho de 2002. Institui, no âmbito da União, Estados, Distrito Federal e Municípios, nos termos do art. 37, inciso XXI, da Constituição Federal, modalidade de licitação denominada Pregão, para aquisição de bens e serviços comuns, e dá outras providências. Brasília, DF. Disponível em: http://www.planalto.gov.br/ccivil_03/LEIS/2002/ L10520.htm

8. Santana JE, Camarão T, Chrispim CD. Termo de Referência; o impacto da especificação do objeto e do termo de referência na eficácia das licitações e contratos.5a Edição. Belo Horizonte, Editora Fórum, 2016: 203.

9. Oliveira MA, Bermudes JAZ, Osório-De-Castro CGS. Assistência farmacêu-

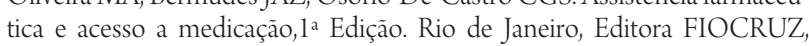
2007:13-26.

10. Citadini AR. Comentários e Jurisprudência Sobre a Lei de Licitações Públicas.3ª Edição. São Paulo, Editora Max Limonad, 1999: 201.

11. Merisio A, Kleba ME, Silva NC, et al. A aquisição de medicamentos para o Sistema Único de Saúde em municípios de pequeno porte do Estado de Santa Catarina. Rev. Bras. Farm., 2012, 93 (2):173-178.

12. Pereira NC, Luiza VL, Cruz MM. Serviços farmacêuticos na atenção primária no município do Rio de Janeiro: um estudo de avaliabilidade. Rev. Saúde Debate, 2015, 39 (105):451-468

13. Brito EA. Aquisição de medicamentos pela Administração Pública: judicialização e controle pelo Tribunal de Contas. Revista TCEMG, 2015, 33 (1):31-61.

14. Luiza VL, Osório-De-Castro CGS, Nunes JM. Aquisição de medicamentos no setor público: o binômio qualidade - custo. Caderno de Saúde Pública ENSP/FIOCRUZ, 1999, 15 (4):769-776.

15. Osório-De-Castro CGS, Ribeiro DCS. Protocolo para aquisições de medicamentos em instituições públicas. Rev. Bras. Farm., 1996, 77 (3):85-47.

16. Brazil. Lei no 6.360, de 23 de setembro de 1976. Dispõe sobre a Vigilância Sanitária a que ficam sujeitos os Medicamentos, as Drogas, os Insumos Farmacêuticos e Correlatos, Cosméticos, Saneantes e Outros Produtos, e dá outras Providências. Brasília, DF. Disponível em: http://www.planalto.gov. br/ccivil_03/LEIS/L6360.htm

17. Brazil. Lei no 9.787 de 10 de fevereiro de 1999 . Altera a Lei no 6.360 de 23 de 
setembro de 1976, que dispõe sobre a vigilância sanitária, estabelece o medicamento genérico, dispõe sobre a utilização de nomes genéricos em produtos farmacêuticos, e dá outras providências. Brasília, DF. Disponível em: http:// www.planalto.gov.br/ccivil_03/Leis/L9787.htm

18. Brazil. Lei n. 5.991, de 17 de dezembro de 1973. Dispõe sobre o Controle Sanitário do Comércio de Drogas, Medicamentos, Insumos Farmacêuticos e Correlatos, e dá outras Providências. Brasilia, DF. Disponível em: http:// www.planalto.gov.br/ccivil_03/leis/15991.htm

19. Brazil. Ministry of Health. Portaria $n^{\circ} 2.814$, de 29 de maio de 1998. Estabelece procedimentos a serem observados pelas empresas produtoras, importadoras, distribuidoras e do comercio farmacêutico, objetivando a comprovação, em caráter de urgência, da identidade e qualidade de medicamento objeto de denúncia sobre possível falsificação, adulteração e fraude. Brasília, DF. Disponível em: http://www.comprasnet.gov.br/PortalCompras/ portais/medicamento/livre/Legislacao\%5Cpor_2814_98.pdf

20. Brazil. Ministry of Health. Portaria $n^{\circ} 2.894$, de 12 de setembro de 2018 Revoga o inciso III do art. $5^{\circ}$ da Portaria $n^{\circ} 2.814 / \mathrm{GM} / \mathrm{MS}$, de 29 de maio de 1998. Brasília, DF. Disponível em: http://bvsms.saude.gov.br/bvs/saudelegis/gm/2018/prt2894_13_09_2018.html

21. Brazil. MPOG/MS/MCT/MDIC. Portaria Interministerial no 1.409, de 18 de maio de 2018. Altera a Portaria Interministerial no 128, de 29 de maio de 2008 que estabelece Diretrizes para a Contratação Pública de Medicamentos e Fármacos pelo Sistema Único de Saúde. Brasilia, DF. Disponível em: http:// www.in.gov.br/materia/-/asset publisher/Kujrw0TZC2Mb/content/ id/15140084/do1-2018-05-21-portaria-interministerial-n-1-409-mpog-ms-mctic-mdic-de-18-de-maio-de-2018-15140080

22. Brazil. MPOG/MS/MCT/MDIC. Portaria Interministerial no 128 , de 29 de maio de 2008. Estabelece Diretrizes para a Contratação Pública de Medicamentos e Fármacos pelo Sistema Único de Saúde. Brasília, DF. Disponível em: http://www.comprasnet.gov.br/legislacao/portarias/p128_08.htm

23. Brazil. Tribunal de Contas da União. Orientações para aquisições públicas de medicamentos. Brasilia: TCU, Secretaria-Geral de Controle Externo (Segecex), Secretaria de Controle Externo da Saúde (SecexSaúde), 2018. $128 \mathrm{p}$.

24. Brazil. Tribunal de Contas da União. Acórdão no 4788/2016. Previsão em normativo interno de exigência de certificado de boas práticas de fabricação e controle como requisito de habilitação técnica nas licitações de medicamentos. Disponível em: https:// contas.tcu.gov.br/juris/SvlHighLight?key=41434f5244414f2d434f4d504c45544f2d31373334363332\&sort=RELEV ANCIA\&ordem=DESC\&bases=ACORDAO=-COMPLETO; \&highlight \&posicaoDocumento $=0 \&$ numDocumento $=1 \&$ totalDocumentos $=1$ Access on: 15NOV2016.

25. Brazil. Tribunal de Contas da União. Acórdão no 7783-33/15-2. Relatados e discutidos autos de representação, com pedido de cautelar suspensiva, formulada pela empresa HospMedic Comércio de Medicamentos e Produtos Hospitalares - Eireli ME sobre suposta irregularidade no edital do Pregão Presencial no 79/2014, promovido pela Fundação Municipal de Saúde de Teresina/PI, cujo objeto consistia na aquisição de medicamentos, por meio de sistema de registro de preços. Disponível em: www.tcu.gov.br/Consultas/ Juris/Docs/judoc/.../20157783/AC_7783_33_15_P.doc

26. Brasil, Tribunal de Contas da União. Acórdão n 2368/2013. A exigência de apresentação de amostras é compatível com as licitações realizadas mediante pregão, inclusive na forma eletrônica, e deve ser requerida na fase de classificação das propostas e somente do licitante provisoriamente classificado em primeiro lugar. Disponível em: http://www.tcu.gov.br/Consultas/Juris/Docs/ judoc/Acord/20130905/AC_2368_34_13_P.doc

27. Brasil, Supremo Tribunal Federal, Aditamento no 4105 MC/DF, deferiu medida cautelar em ação direta de inconstitucionalidade para suspender a eficácia do $\$ 3^{\circ}$ do art. $5^{\circ}$ da Portaria 2.814/98, do Ministério da Saúde. Disponível em: http://www.stf.jus.br/arquivo/informativo/documento/
informativo579.htm\#ADI\%20e\%20Exig\%C3\%AAncia\%20em\%20Licita\%$\mathrm{C} 3 \% \mathrm{~A} 7 \% \mathrm{C} 3 \% \mathrm{~A} 3 \mathrm{O}$

28. Brasil, Lei Complementar no 101, de 04 de maio de 2000. Estabelece normas de finanças públicas voltadas para a responsabilidade na gestão fiscal e dá outras providências. Brasília, DF. Disponível em: http://www.planalto.gov. $\mathrm{br} /$ ccivil_03/leis/lcp/lcp101.htm

29. Brasil, Tribunal de Contas da União. Acórdão no 8518/2017. Recomenda que inclua, nos editais de licitações e contratos, cláusula relativa à aplicação do Convênio ICMS CONFAZ 87/2002 ou de outras normas que impliquem desoneração tributária, de modo a assegurar a isonomia entre os participantes, a publicidade e a obtenção da proposta mais vantajosa para a Administração Pública. Brasília, DF. Disponível em: https://pesquisa.apps. tcu.gov.br/\#/documento/acordao-completo/4452420129.PROC/\%20/ DTRELEVANCIA\%20desc,\%20NUMACORDAOINT\%20desc/0/\%20 ?uuid=bb568270-bd6b-1 le9-894a-4f8868a2e97a

30. Brazil. CONFAZ. Convênio ICMS 87/2002. Concede isenção do ICMS nas operações com fármacos e medicamentos destinados a órgãos da Administração Pública Direta Federal, Estadual e Municipal e suas alterações. Disponível em: https://www.confaz.fazenda.gov.br/legislacao/convenios/2002/CV087_02

31. Brazil. Lei no. 9.782 de 26 de janeiro de 1999. Define o Sistema Nacional de Vigilância Sanitária, cria a Agência Nacional de Vigilância Sanitária, e dá outras providências. Brasília, DF. Disponível em: http://www.planalto.gov. br/ccivil 03/LEIS/L9782.htm

32. Brazil. Ministry of Health. Portaria no 1.818 , de 02 de dezembro de 1997. Recomenda que nas compras e licitacoes de produtos farmaceuticos realizadas nos niveis federal, estadual e municipal pelos servicos governamentais, conveniados e contratados pelo SUS, sejam incluidas exigencias sobre requisitos de qualidade a serem cumpridas pelos fabricantes desses produtos. Brasília, DF. Disponível em: http://bvsms.saude.gov.br/bvs/saudelegis/gm/2014/ prt1818_26_08_2014.html

33. Brazil. Ministry of Health. Portaria no 802 , de 08 de outubro de 1998. Institui o Sistema de Controle e Fiscalização em toda a cadeia dos produtos farmacêuticos. Brasília, DF. Disponível em: http://bvsms.saude.gov.br/bvs/saudelegis/anvisa/1998/prt0802_08_10_1998.html

34. Brazil. Ministry of Health. Portaria no. 344, de 15 de maio de 1998. Aprovar o Regulamento Técnico sobre substâncias e medicamentos sujeitos a controle especial. DOU, Brasília, DF. Disponível em: http://bvsms.saude.gov.br/bvs/ saudelegis/svs/1998/prt0344_12_05_1998_rep.html

35. Brasil. ANVISA. Resolução - RDC no 333, de 19 de novembro de 2003 Dispõe sobre rotulagem de medicamentos e outras providências. Brasília, DF. Disponível em: http://bvsms.saude.gov.br/bvs/saudelegis/anvisa/2003/ rdc0333_19_11_2003.html

36. Brazil. ANVISA. Resolução - RDC no 199, de 26 de outubro de 2006. Institui a notificação simplificada de medicamentos mediante peticionamento eletrônico. Brasília, DF. Disponível em: http://bvsms.saude.gov.br/bvs/saudelegis/anvisa/2006/res0199_26_10_2006.html

37. Brazil. ANVISA. Resolução -RDC no 71, de 22 de dezembro de 2009. Estabelece regras para a rotulagem de medicamentos. Brasilia, DF. Disponível em: http://bvsms.saude.gov.br/bvs/saudelegis/anvisa/2009/ res0071_22_12_2009.html 